\title{
Diversity, Ecology and Survivor of Freshwater Red Algae in Israel
}

\author{
S. Barinova \\ Institute of Evolution, University of Haifa, Mount Carmel, Haifa 31905, Israel \\ *Corresponding Author: barinova@research.haifa.ac.il
}

Copyright $@ 2013$ Horizon Research Publishing All rights reserved.

\begin{abstract}
From 1950s till now only seven species of Rhodophyta were recorded from continental waters of Israel. Among them, the most abundant are the species of Audouinella that inhabit fresh or brackish waters of lakes, pools and rivers. Our findings of two species of this genus inhabiting the fresh clear water Oren River, the middle reaches of the polluted Qishon River (A. pygmaea (Kütz.) Weber-van Bosse)), as well as the middle reaches of the strongly impacted Lower Jordan River ( $A$. hermannii (Roth) Duby in De Candolle). These findings led us to conclude the latter species preferred low to moderate salinity and a high calcium concentration and is relatively resistant to organic pollution. Bangia atropurpurea (Mertens ex Roth) C. Agardh and Hildenbrandia rivularis (Liebmann) J. Agardh are the sensitive species sporadically observed in a few habitats only and preferring the slightly mineralized slow streaming carbonate waters with insignificant organic pollution. Batrachospermum gelatinosum (Linnaeus) De Candolle is only one new for Israel species that has been found in the Meshushim stream. The likewise sensitive Phragmonema sordidum Zopf is consider as a lost species because of the loss of habitat. We do not confirm finding of red algae Paralemanea catenata (Kützing) Vis et Sheath in the Banias stream.
\end{abstract}

Keywords Freshwater Algae, Red Algae, Rare Species, Algal Diversity, Phytogeography, Israel

\section{Introduction}

Israel presents a unique diversity of algal environments for such a small territory. The freshwater algae are collected from a wide range of altitudinal belts, from the coastal realms recognized on the basis of the higher plant differentiation [1,2].

The red algae division comprises over 5,000 different species but no more than 200 species are found in fresh waters $[3,4]$ inhabiting rivers and streams and less common in still waters $[5,6]$. They are ecologically significant as primary producers, providing habitats for other organisms.
In streaming waters, red algae attach to stones, rocks and other hard substrates. Their distribution and abundances are controlled by their high sensitivity to environmental impacts.

Freshwater red algae therefore are the best object for indication of environment assessment and protected area monitoring. Israel territory is much enriched by protected areas which considerable related to aquatic habitats. In the Mediterranean region known few causes for biodiversity protected area monitoring and control [7]. One of them is human activities. In the Mediterranean region several protection initiatives have been outlined over the past decade to significantly reduce the current rate of biodiversity loss at global, regional, and national levels.

A critical analysis of the most recent aquatic habitat list produced for the Mediterranean region for Specially Protected Areas showed that our knowledge about habitats and associated species considered in the list are scarcely covered by scientific knowledge from Web-based resources, and quantitative information about the geographical distribution of selected habitats and associated species is scant. The combination of mapping of important species and its habitat classifications will allow better estimates of biodiversity distribution in Mediterranean region, to reverse regional/global habitat loss rates [7].

The aim of present study is to summarize taxonomical information about freshwater red algae and its distribution, and reveal ecological preferences of each found species in environmental and climatic gradients in Israel.

\section{Materials and Methods}

Present Red algae were first found in Israel in the 1950s $[8,9]$, and till our investigation only six species were reported from continental waters, most of which belong to Audouinella [10-12]. Our studies during 2001-2013 of freshwater algal diversity in Mediterranean coastal rivers and mountain rivers of northern Israel provide contributed about 670 species which come from 1960 studied samples. As a result, the algal flora of Israel now comprises 1,662 species and infraspecies of 11 taxonomic divisions. In the course of these studies we found red freshwater algae 
Audouinella pygmaea (Kützing) Weber-van Bosse in the Oren and Qishon rivers and A. hermannii (Roth) Duby in the Lower Jordan River [13-18]. Batrachospermum gelatinosum was found in first for the Eastern Medeterranean in the Meshushim stream [19]. The findings of red algae Paralemanea catenata [8], which was previously discovered in the Banias Stream in the piedmonts of Mount Hermon, Northern Israel by Rayss in 1951 [8] has been not confirmed.

Measurements of environmental variables were made during the field trips as well as in the laboratory. The material for this study came from 38 samples of periphyton collected during 29 sampling trips over the Northern and Central Israel (Figure 1). The sampling was conducted in 2001-2012 for both dry and wet seasons. We sampled permanent water flows in the upper reaches and tributaries, as well as intermittent water bodies in the lower reaches of rivers and streams. Each sampling site and habitat was photographed. The samples were obtained by scratching for periphyton and were preserved in 3\% formaldehyde. Algae were studied with a dissecting Swift microscope under magnifications $740-1850$ and were photographed with the digital camera Inspector 1 as well as with Nikon microscope under magnifications 800-2000 with the digital camera Leica 320.

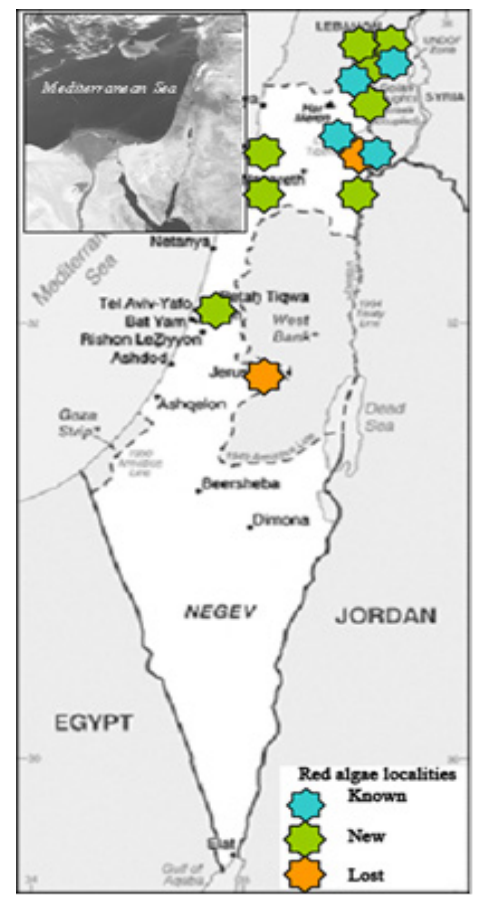

Figure 1. Sites of red algae in Israel: the new, validated, and lost habitats.

In parallel with sampling for algae we measured temperature, conductivity, Total Dissolved Solids (TDS), and $\mathrm{pH}$ with HANNA HI 9813 (Table 1). The TDS is correlated with chloride concentration (salinity) and water conductivity [20]. The TDS was measured when conductivity level decreased below $1000 \mathrm{mSm} / \mathrm{cm}$.

The ecological and geographical characteristics of algal species are obtained from our database for multipurpose analysis of freshwater algal biodiversity of Israel. Taxonomy of studied species was verified with algaebase.org [21].

Our description and ecological analysis add to morphology and ecology of Batrachospermum gelatinosum, rare species found in first for Israel.

\section{Results and Discussion}

Distribution of seven Rhodophyta species found in continental waters of Israel is shown in Figure 1. Our analysis reveals a few lost habitats, as well as a few recently found new habitats [18,22]. Table 1 represented the tolerance limits for each of the species of red algae found in Israel in respect of the major environmental variables. For the previously recorded species referred to in the literature, but not found in our samples we provide environmental data for the habitats indicated in the reference.

As can be seen in Figure 1, the red algal habitats of the northern and central parts of Israel are confined to the area of temperate arid or semi-arid climate. Our studies in the temporal streams and the moisturized habitats of the Negev failed to reveal any Rhodophyta species.

The recent statistical analysis of algal distribution highlighted of six phytogeographic domains [23]. Four clusters of diatom taxa, which are most abundant and occur in all moisturized habitats, correspond to the habitats of coastal plains (I), the Judean and Galilean highlands (II), piedmonts (III), and the Dead Sea - Kinneret Lake Rift Valley. The red algae fall in clusters I - III, those of cluster IV are found in the northern Israel alone.

Our studies on ecology and phytogeography of the red algae found in Israel are summarized below (Table 1).

\section{Paralemanea catenata (Kützing) Vis et Sheath}

This species was listed without description by Rayss in 1951 in the Banias locality at $33^{\circ} 14^{\prime} 52^{\prime \prime} \mathrm{N}$ and $35^{\circ} 41^{\prime} 33^{\prime \prime} \mathrm{E}$ and $350 \mathrm{~m}$ above sea level (a.s.1.) from which we erroneously described Lemanea fluviatilis (Linnaeus) J. Agardh [24]. However, Paralemanea was not found. Lemanea and Paralemanea are quite morphologically and their ecological ranges overlap. We suspect that a red alga assigned to Paralemanea catenata by Rayss might have been found in this protected area locality. Anyway the environmental characteristic is placed in Table 1. The Banias Stream is located in the Upper Jordan River Basin in the piedmonts of Mount Hermon, Northern Israel at $361 \mathrm{~m}$ above sea level. It flow on basalt pebbles covered with carbonate crust in the slow flowing, cool-temperate, alkalic waters of low salinity and insignificant organic pollution in the protected area of the Banias National Park. The Banias stream is the only place in Israel corresponding to the ecological requirements of the species, which makes it a unique conservation object. We found seasonal variation of water quality in the stream related to anthropogenic impact during the tourist season [25] when special conservation measures must be taken. 


\section{Bangia atropurpurea (Roth) J. Agardh}

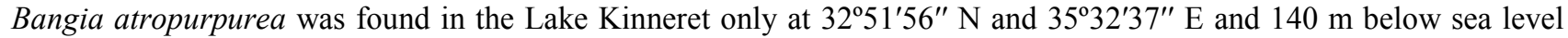
(b.s.1.). It has been first reported without description by Inka Dor [11]. In 2007 it was collected by Dr. Alla Alster and studied by us (Figure 2). This species is rare in terms of its sparse localities, but forms abundantly growing populations. Unfortunately, periphytic algae are only sporadically studied in the Lake Kinneret. Environmental variables of phytoplankton habitats in the Lake Kenneret are reviewed in [26]. Our studies of periphyton diversity and environmental conditions highlighted the Lake Kinneret habitats as unpolluted, of temperate water temperatures, low alkalinity, and low to moderate mineralization (Table 1).

Table 1. The tolerance ranges for species of red algae found in Israel. $\mathrm{T}$ - water temperature, $\mathrm{pH}-$ water acidity, $\mathrm{E}-$ water conductivity, $\mathrm{TDS}-\mathrm{Total}$

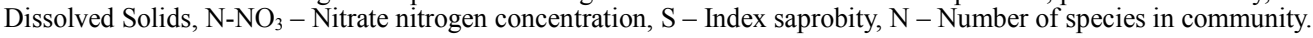

\begin{tabular}{|c|c|c|c|c|c|c|c|c|}
\hline Habitat & Species & $\mathrm{T},{ }^{\circ} \mathrm{C}$ & $\mathrm{pH}$ & $\mathrm{E}, \mathrm{ms} / \mathrm{cm}$ & $\mathrm{TDS}, \mathrm{mg} / \mathrm{l}$ & $\mathrm{N}-\mathrm{NO}_{3} \mathrm{mg} / \mathrm{L}$ & $\mathrm{S}$ & $\mathrm{N}$ \\
\hline Lower Jordan & Audouinella hermannii & $22-29$ & $7.3-7.5$ & $5.93-6.46$ & $>1000$ & $3.4-4.4$ & $1.41-1.63$ & $24-27$ \\
\hline Yarqon & Audouinella pygmaea & $14-25$ & $7.4-8.03$ & $0.81-1.26$ & $584-614$ & $0.5-6.5$ & $2.18-2.56$ & $12-40$ \\
\hline Oren & Audouinella pygmaea & $12.5-21.5$ & $7.5-8.2$ & $0.68-0.85$ & $490-623$ & $0.3-2.3$ & $1.44-2.23$ & $5-37$ \\
\hline Qishon & Audouinella pygmaea & $14-31$ & $7.1-8.4$ & $0.84-10.66$ & $606-780$ & $0.8-5.6$ & $2.03-2.38$ & $8-36$ \\
\hline Upper Jordan & Audouinella pygmaea & $14-30.5$ & $6.9-8.38$ & $0.33-0.49$ & $236-865$ & $0-2.25$ & $1.11-1.94$ & $7-42$ \\
\hline Dan, Banias & Hildenbrandia rivularis & $14.8-19.5$ & $6.9-8.3$ & $0.26-0.49$ & $187-302$ & $2.3-3.0$ & $1.40-2.40$ & $7-14$ \\
\hline Jerusalem & Phragmonema sordidum & - & - & - & - & - & - & - \\
\hline Kinneret & Bangia atropurpurea & $15.5-35$ & $6.6-8.0$ & $0.82-4.0$ & $593-1040$ & $0.1-0.7$ & $1.23-1.78$ & $7-18$ \\
\hline Banias & Paralemanea catenata & $14.8-18$ & $6.9-7.9$ & $0.26-0.49$ & $187-302$ & $2.3-3.0$ & $1.47-1.60$ & $8-9$ \\
\hline Kinneret & Audouinella sp. & $15.5-35$ & $6.6-8.0$ & $0.82-4.0$ & $593-1040$ & $0.1-0.7$ & $1.23-1.78$ & $7-18$ \\
\hline
\end{tabular}
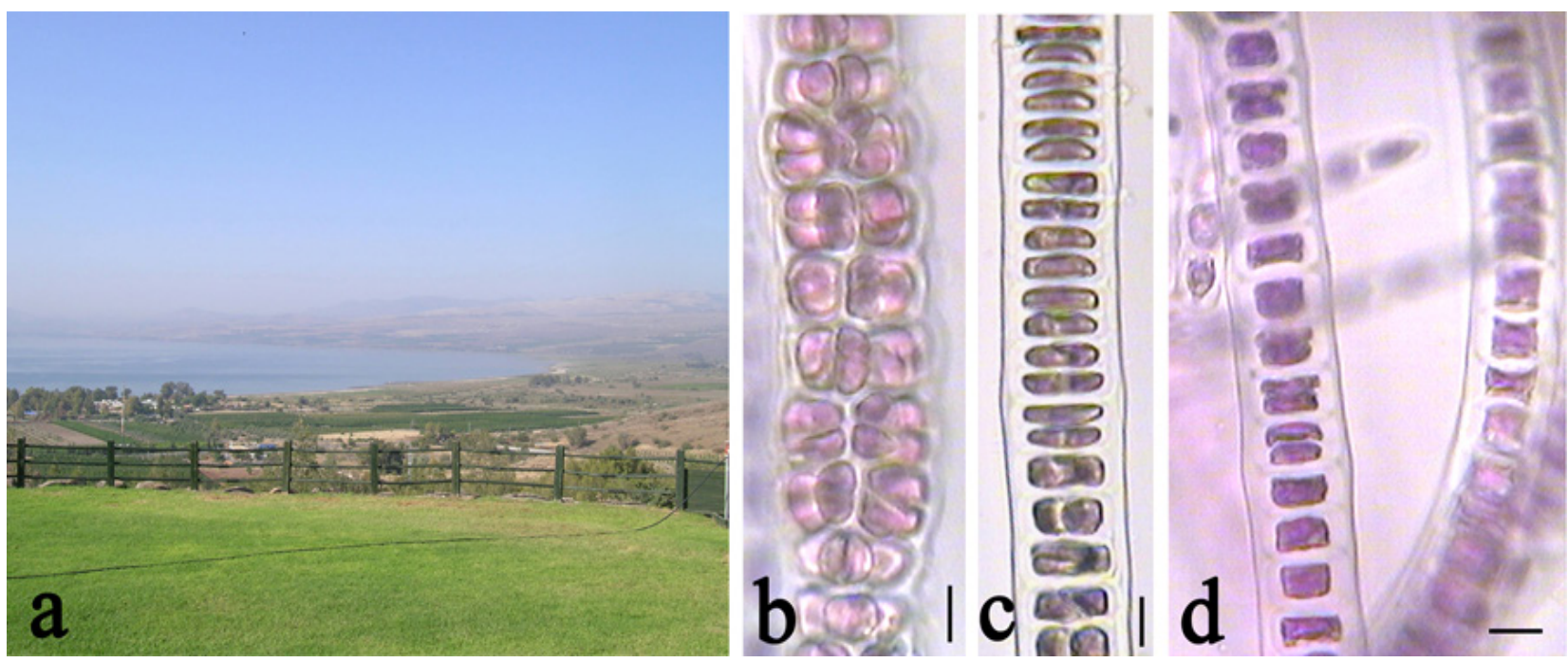

Figure 2. Bangia atropurpurea: a - habitat, b, c, d-parts of thalluses. Scale bar: $15 \mathrm{mkm}$.

\section{Hildenbrandia rivularis (Liebmann) J. Agardh}

The species has been first found in the Dan Stream at 33 $14^{\prime} 04^{\prime \prime} \mathrm{N}$ and $35^{\circ} 38^{\prime} 12^{\prime \prime} \mathrm{E}$ and about $120 \mathrm{~m}$ above sea level (a.s.1.), the Upper Jordan River Basin in the piedmonts of Mount Hermon, Northern Israel [10]. We confirmed these occurrences in 2008. In 2009 we found one more locality of Hildenbrandia rivularis in the Banias stream at $33^{\circ} 14^{\prime} 52^{\prime \prime} \mathrm{N}$ and $35^{\circ} 41^{\prime} 33^{\prime \prime} \mathrm{E}$ and $350 \mathrm{~m}$ above sea level (a.s.1.), a tributary of the Upper Jordan River (Figure 3). This species inhabits low alkaline, temperate, slow streaming, clear, unpolluted water mostly in the winter cool shadowed water (Table 1). Having a rather broad range of ecological tolerance, it can be expected in other places under conditions similar to those of the Banias and Dan. 

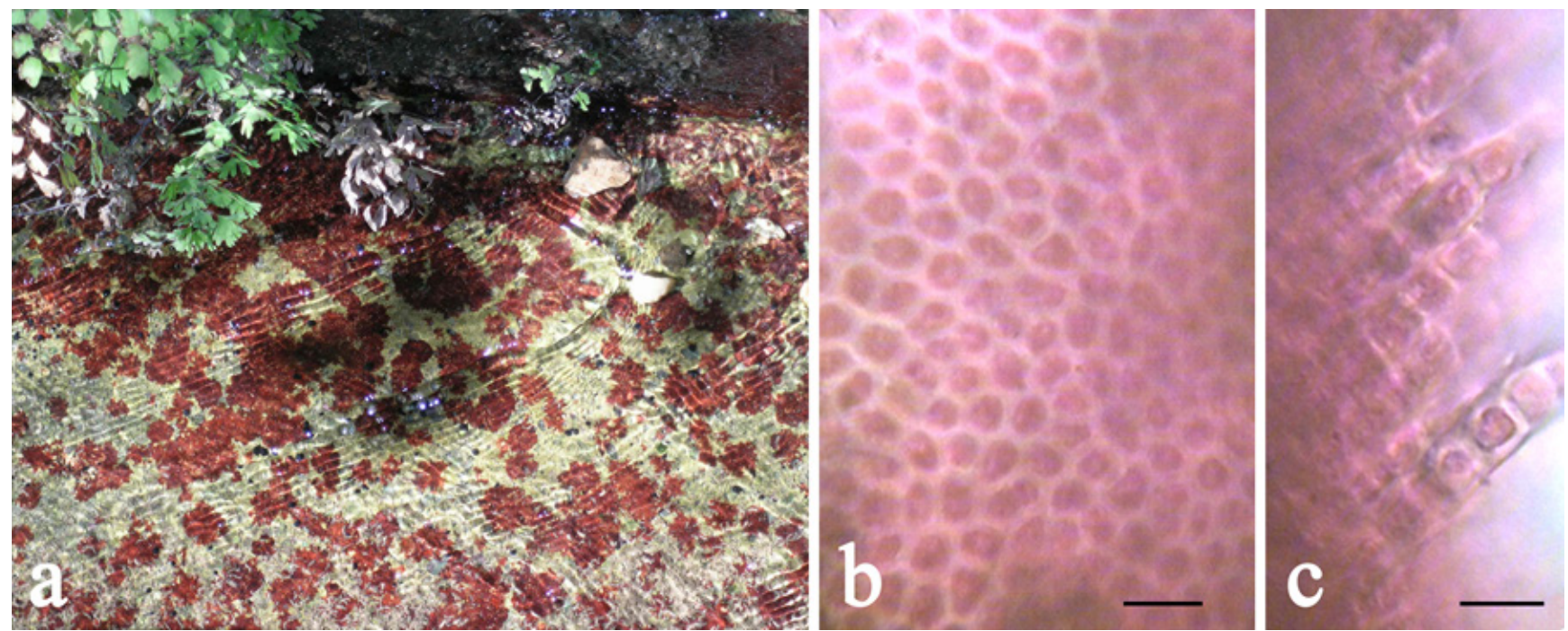

Figure 3. Hildenbrandia rivularis: $\mathrm{a}$ - habitat, $\mathrm{b}$ - part of thallus, surface view, $\mathrm{c}$ - filaments of thallus. Scale bar: $10 \mathrm{mkm}$.

\section{Audouinella hermannii (Roth) Duby in De Candolle}

This species was found twice at the Gesher in the Lower Jordan during 2005 and 2007 field trips (Figure 4). It can be considered as alkaliphilic inhabiting moderately mineralized and moderately organically polluted slow streaming rivers (Table 1). In the Lower Jordan River, it survives under a heavy impact of organic and toxic substances which come with wastewater of Bitania and Saline Water Carrier below the Lake Kinneret [16]. Therefore, it can be found under similar conditions over a wide range of habitats.
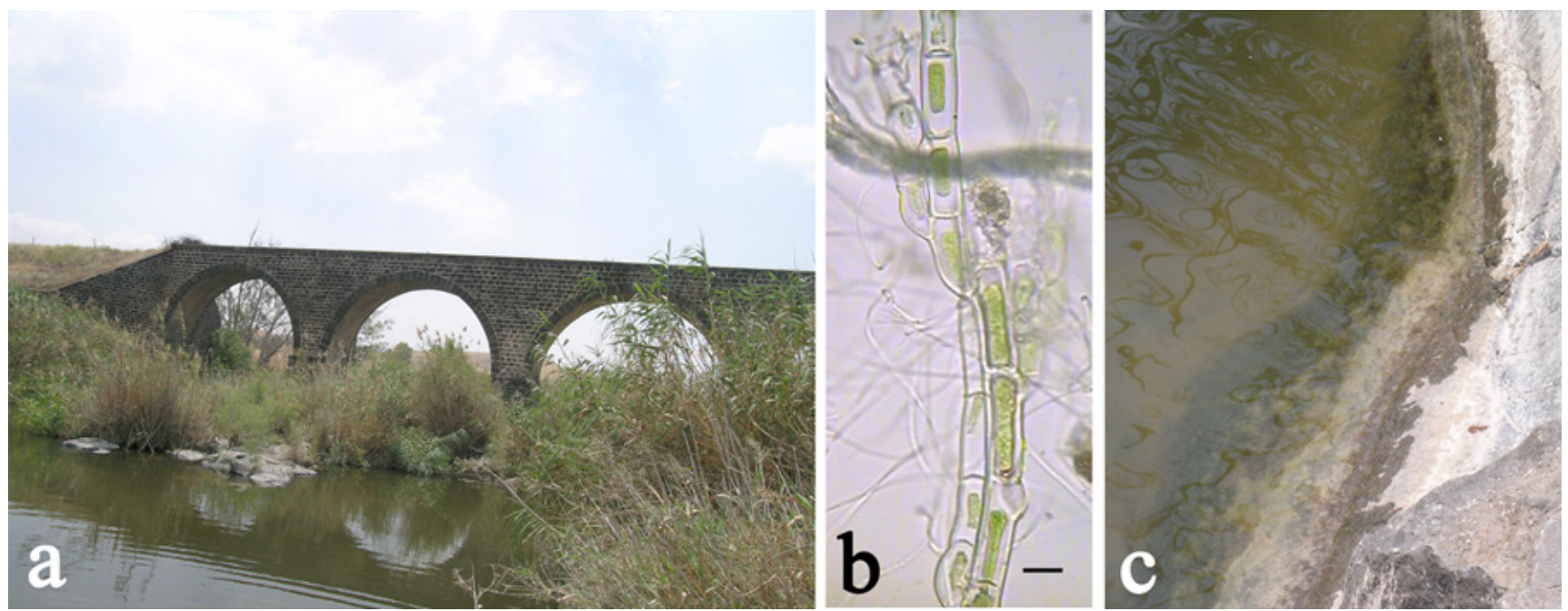

Figure 4. Audouinella hermannii: $\mathrm{a}$ - habitat, $\mathrm{b}$ - part of thallus, $\mathrm{c}$ - community of Audouinella hermannii in habitat. Scale bar: $10 \mathrm{mkm}$.

\section{Audouinella pygmaea (Kützing) Weber-van Bosse}

Among the freshwater red algae of Israel, the most abundant are Audouinella species, which inhabit fresh or brackish waters of inland lakes, pools and springs (Figure 5). For the first time in Israel, we found two species of Audouinella, which inhabit fresh clear waters of the Oren River at $32^{\circ} 43^{\prime} 26^{\prime \prime} \mathrm{N}$ and $35^{\circ} 00^{\prime} 53^{\prime \prime} \mathrm{E}$ and $250 \mathrm{~m}$ above sea level (a.s.l.) [14,27] (Table 1), the upper reaches of the moderately polluted Yarqon River at $32^{\circ} 07^{\prime} 27^{\prime \prime} \mathrm{N}$ and $34^{\circ} 53^{\prime} 14^{\prime \prime} \mathrm{E}$ and $20 \mathrm{~m}$ a.s.l. [28], the middle reaches of the heavily polluted Qishon River at $32^{\circ} 40^{\prime} 50^{\prime \prime} \mathrm{N}$ and $35^{\circ} 07^{\prime} 14^{\prime \prime} \mathrm{E}$ and $25 \mathrm{~m}$ a.s.l. (A. pygmaea) [15], as well as the middle reaches of the strongly impacted Lower Jordan River at 32 $37^{\prime} 28^{\prime \prime} \mathrm{N}$ and $35^{\circ} 33^{\prime} 54^{\prime \prime}$ E and $257 \mathrm{~m}$ below sea level (b.s.l.) (A. hermannii) [16].

The broad ranges of environmental pollution as well as statistical analysis by CCA (Canonical Correspondence Analysis) [29] led as to conclude that these two species preferred low to middle salinity and a high calcium concentration. They are more resistant to organic pollution than previously supposed in the references [30,31].

Because of their high tolerance to salinity and pollution, a high $\mathrm{pH}$ being practically the only limiting factor, Audouinella species can be found in the other rivers, as well as in the Lake Kinneret. 

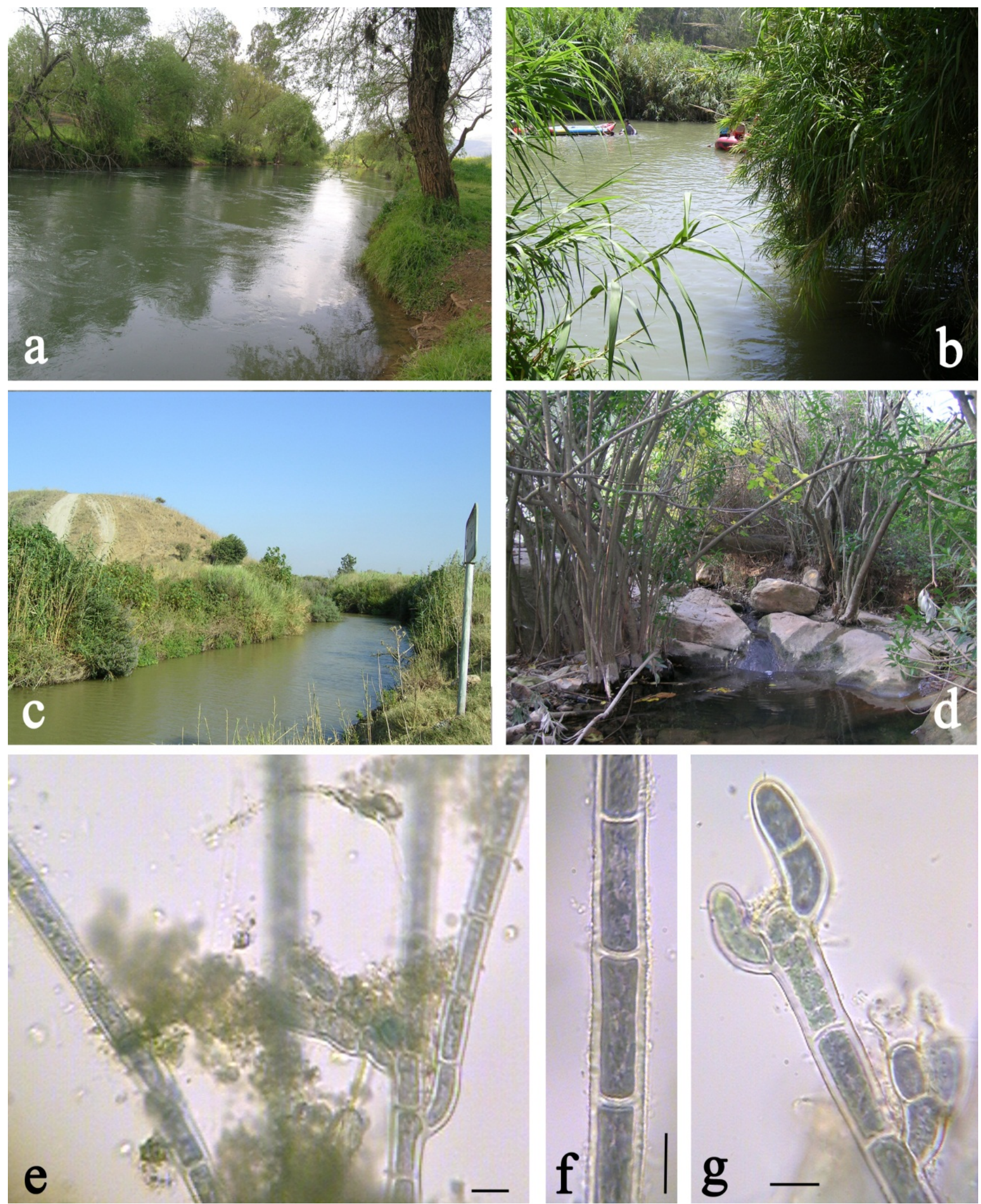

Figure 5. Audouinella pygmea: habitat in a - Upper Jordan River, middle reaches, b - Upper Jordan River near the Lake Kinneret, c - Qishon River, middle reaches, $\mathrm{d}$ - Oren River, upper reaches, $\mathrm{e}$ - species view, $\mathrm{f}, \mathrm{g}$ - parts of filaments. Scale bar: $10 \mathrm{mkm}$. 


\section{Phragmonema sordidum (Liebmann) J. Agardh}

This species was mentioned without morphological description and illustration in Friedmann [9]. It was found in a small water pool near Jerusalem in Beit Guvrin-Maresha National Park in central Israel, 13 kilometers from Kiryat Gat on $31^{\circ} 36^{\prime} 47.15^{\prime \prime} \mathrm{N}$ and $34^{\circ} 53^{\prime} 53.87^{\prime \prime} \mathrm{E}$ and $280 \mathrm{~m}$ above sea level. Now this water pool is empty and therefore it let us to conclude that species is lost because lost its only once habitat.

First finding in Israel of Batrachospermum gelatinosum (Linnaeus) De Candolle

A rare, freshwater red algae, and Israel newcomer, Batrachospermum gelatinosum, was found once during 2009 field trips (Figure 6) in the Meshushim pool placed in upper reaches of the Meshushim stream, the small stream of the mountainous area of the Upper Jordan Basin at 32 $58^{\prime} 19.20^{\prime \prime}$ $\mathrm{N}$ and 35039'19.0" $\mathrm{E}$ and $390 \mathrm{~m}$ above sea level which followed from the Golan Heights to the Lake Kinneret.

The environmental conditions measured during those periods are presented in Table 2. It can be considered as alkaliphilic inhabiting moderately mineralized and low organically polluted streaming rivers.

Table 2. Environmental variables measured in the Meshushim pool in winter 2009.

\begin{tabular}{|c|c|}
\hline Parameters & $\begin{array}{c}\text { Normal range in the Meshushim pool in } \\
2009\end{array}$ \\
\hline $\mathrm{T}\left({ }^{\circ} \mathrm{C}\right)$ & 20.2 \\
\hline Depth, cm & $10-30$ \\
\hline Electrical Conductivity $(\mu \mathrm{s} / \mathrm{cm})$ & 370.0 \\
\hline $\mathrm{pH}$ & 8.3 \\
\hline TDS (mg/l) & 264 \\
\hline $\begin{array}{c}\text { Index of Saprobity }(\mathrm{S}) \\
\text { No. of Species in algal } \\
\text { community }\end{array}$ & $1.0-1.69$ \\
\hline
\end{tabular}

Taxonomy of the Batrachospermum gelatinosum is given after T. Cavalier-Smith [21].
Systematic description

Kingdom: Plantae

Phylum: Rhodophyta

Class: Florideophyceae

Order: Batrachospermales

Family: Batrachospermaceae

Genus: Batrachospermum

Species: Batrachospermum gelatinosum (Linnaeus) De Candolle

Major synonym: Batrachospermum moniliforme Roth

Description: Filaments grey, olive-green slightly violet to brown with spherical or barrel-shaped whorls that are separated to confluent, $250-800 \mu \mathrm{m}$ in diameter at reproductive maturity, $1.5-6 \mathrm{~cm}$ long; main axis with cortication consisting of cylindrical cells only; monoecious. Female plants of 1-3 spherical carposporophytes scattered within the whorl, $60-90 \mu \mathrm{m}$ in diameter with 2-5 gonimoblast cells per branch, carpogonia 30-50 $\mu \mathrm{m}$ long with club-shaped or occasionally lance-shaped trichogynes 8-13 $\mu \mathrm{m}$ in diameter. Carpogonial branch undifferentiated, 3-10 cells long. Carposporogonia ovoid, 8-11 $\mu \mathrm{m}$ in diameter, 8-16 $\mu \mathrm{m}$ long. Figure 6 presents the view of the plant and its parts.

Habitat: On carbonates covered with thick carbonate sediment in middle streaming water at depths $10-30 \mathrm{~cm}$ partly shaded or well-illuminated.

Distribution: Northern Hemisphere - North America, Finland, England and Wales, Czech Republic, Spain, Germany, Italy, Norway, Romania, Slovenia, France, India, Russian Far East, Japan, Malaysia, Israel. Southern Hemisphere - Australia and New Zealand.

Batrachospermum gelatinosum was found in clear, low mineralized alkaline water $(\mathrm{pH}>7.5)$ in a species enriched community together with second red algae species, Audouinella pygmaea. Both species indicate the presence of xenosaprobic waters that reflect on the Saprobity Index S, which ranged from 1.0 to 1.69. It mentioned in [4] as indicator of oligotrophic to mesotrophic waters. Therefore, it can be concluded that the upper reaches of the Meshushim stream are naturally clean and red algae species Batrachospermum gelatinosum can be used as indicator of natural condition in this locality. 

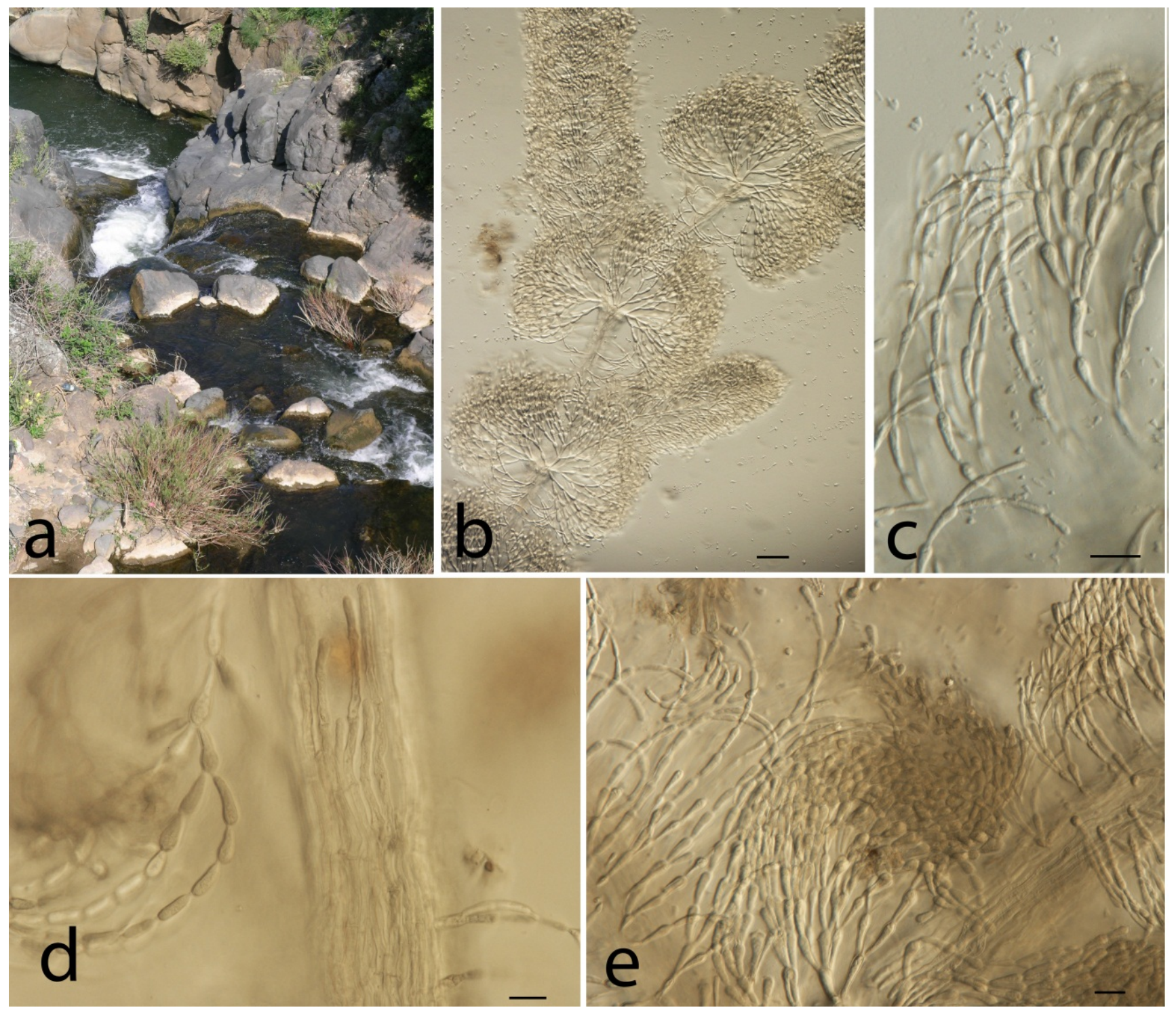

Figure 6. Batrachospermum gelatinosum from the upper Meshushim stream: $\mathrm{a}$ - habitat in the Meshushim pool in the Meshushim stream upper reaches; $\mathrm{b}$ - species view, $\mathrm{c}$ - spermatangia terminal on the fascicles; $\mathrm{d}$ - main axis with long cylindrical cortical cells; $\mathrm{e}$ - parts of filament with carposporophyte. Scale bar: b- $100 \mathrm{mkm}, \mathrm{c}, \mathrm{d}, \mathrm{e}-20 \mathrm{mkm}$.

\section{Conclusion}

The analysis of the literature reviewed on freshwater red algae in Israel revealed five species for one which only generic assignment was available: Bangia atropurpurea, Hildenbrandia rivularis, Paralemanea catenata, Phragmonema sordidum, Audouinella sp. Our studies since 2001 have added three more species: Audouinella pygmaea, A. hermannii, Batrachospermum gelatinosum.

The ecology of red algae of Israel attests to a broad range of environmental variables for Audouinella pygmaea and $A$. hermannii. These species are commonly considered to be the clean water indicators. However, we differentiated between the obligatory conditions, i.e. the high carbonate content high $\mathrm{pH}$ waters, and the broad range of accessory variables, for which this group is tolerant. The latter are the mineralization, organic pollution and the level of toxicity.
Another group of red algae comprises inhabitants of clear waters of narrow range of environmental variables, including Hildenbrandia rivularis, Bangia atropurpurea, and Batrachospermum gelatinosum are found in few localities. The two latter species are sporadically distributed in the slightly mineralized high $\mathrm{pH}$ waters. For Hildenbrandia rivularis we found a new locality in the Upper Jordan Basin. For Batrachospermum gelatinosum we found only one locality in the Upper Jordan River basin that is new for Israel.

Our studies indicate broader than previously suspected ecological tolerance of Audouinella, which enables us to exclude two species of this genus occurring in Israel from the high risk category. For the rest of red algae the risks of pollution and loss of habitat are still eminent.

From six red alga species listed in the algal flora of Israel, we consider as dubious Paralemanea catenata [8] form the Banias spring that we cannot found in the locality. 
Audouinella sp. was reported, but not documented by [11] from the Lake Kinneret, in which this genus was not recorded during our survey. We failed to confirm the previously indicated localities of Phragmonema sordidum and its occurrence in Israel.

\section{Acknowledgements}

This work has been partially funded by the Israel Ministry of Absorption.

\section{REFERENCES}

[1] M. Zohary, N. Feinbrun-Dothan. Flora Palaestina, Volumes 1-4, The Israeli Academy of Sciences and Humanities, Jerusalem, 1966-1986

[2] M. Zohary. Flora Palaestina I: Equisetaceae to Moringacea, The Israeli Academy of Sciences and Humanities, Jerusalem, 1966.

[3] H. Skuja. Comments on fresh-water Rhodophyceae, The Botanical Review, Vol.4, No.12, 665-676, 1938.

[4] P. Eloranta, J. Kwandrans. Freshwater Red Algae (Rhodophyta). Identification guide to European taxa, particularly to those in Finland, Norrlinia, Vol.15, 1-103, 2007.

[5] D.J. Garbary, P.W. Gabrielson. Taxonomy and evolution. In: K.M. Cole, R.G. Sheath (eds) Biology of the red algae. Cambridge University Press, Cambridge, 477-498, 1990.

[6] K. Lüning. Seaweeds: Their environment, biogeography, and ecophysiology, Wiley, New York, 1990.

[7] S. Fraschetti, G. Guarnieri, S. Bevilacqua, A. Terlizzi, J. Claudet, G.F. Russo, F. Boero. Conservation of Mediterranean habitats and biodiversity countdowns: what information do we really need?, Aquatic Conserv: Mar. Freshw. Ecosyst., Vol.21, 299-306, 2011.

[8] T. Rayss. Les algaes des aeux continentals, Materiaux paur la flore algologique de la Palestine, Palestine Journal of Botany, Vol.5, 71-95, 1951.

[9] I. Friedmann. Studies on cave-algae from Israel II. Beiträge zur Morphologie und Formwechsel der atmophytischen Bangioidee Phragmonema sordidum Zopf, Österreichische botanische Zeitschrift, Vol.103, No.5, 613-633, 1956.

[10] P. Bourrelly. Ecology of Freshwater Organisms. 2. Algae and other aquatic Plants, Verhandlungen - Internationale Vereinigung für Theoretische und Angewandte Limnologie, Vol.18, 1326-1337, 1973.

[11] I. Dor. Considerations about the composition of benthic algal flora in Lake Kinneret, Hydrobioogia, Vol.44, No.2-3, 255-264, 1974.

[12] E. Nevo, S.P. Wasser (eds). Biodiversity of cyanoprocaryotes, algae and fungi of Israel. Cyanoprocaryotes and algae of continental Israel. A.R.G. Gantner Verlag, Ruggell /Leichtenstein, 2000.
[13] S.S. Barinova, O.V. Anissimova, E. Nevo, M.M. Jarygin, S.P. Wasser. Diversity and Ecology of Algae from Nahal Qishon, Northern Israel. Plant Biosystems, Vol.138, No.3, 245-259, 2004.

[14] S.S. Barinova, O.V. Anissimova, E. Nevo, S. Wasser. Diversity and ecology of phytoplankton and periphyton of the Nahal Oren, Alon Natural Park, Northern Israel, Algological Studies, Vol.116, 169-197, 2005.

[15] S.S. Barinova, O.V. Anissimova, E. Nevo, S.P. Wasser, M.M. Jarygin. Freshwater algae new for Israel found in Nahal Qishon, Flora Mediterranea, Vol.15, 73-98, 2005.

[16] M. Tavassi, S. Barinova, H. Glassman. Algal community in the pollution Lower Jordan River (Israel), Israel Journal Plant Science, Vol.56, No.1-2, 111-119, 2008.

[17] S.S. Barinova, E. Nevo. The Upper Jordan River algal communities are evidence of long-term climatic and anthropogenic impacts, Journal Water Resource and Protection, Vol.2, 507-526, 2010.

[18] S. Barinova. Algal diversity dynamics, ecological assessment, and monitoring in the river ecosystems of the eastern Mediterranean, Nova Science Publishers, New York, USA, 2011.

[19] S.S. Barinova, E. Nevo. Diversity and ecology of freshwater red algae in Israel. First International Congress Documenting, Analysing and Managing Biodiversity in the Middle East (Jorden) October 2008. Aqaba: DAAD, 136. 2008.

[20] A. Ehrlich. Atlas of the inland-water diatom flora of Israel, Israel Academy of Science and Humanities, Jerusalem, 1995.

[21] M.D. Guiry, G.M. Guiry. AlgaeBase. World-wide electronic publication, National University of Ireland, Galway. Online available from http://www.algaebase.org; searched on 16 July 2013.

[22] E. Lipkovsky, S. Barinova, B. Teltsch, E. Nevo. Algal vegetative activity in the Upper Jordan River (Northern Israel): an in vitro glass slide experiment. Applied Ecology and Environmental Research, 9(3): 231-244, 2011.

[23] S. Barinova. The effect of altitude on distribution of freshwater algae in continental Israel, Current Topics in Plant Biology, Vol.12, 89-95, 2011.

[24] S. Barinova, E. Lipkovsky, E. Nevo. Rare species Lemanea fluviatilis (L.) Agardh (Rhodophyta) from Israel, Algological Studies, Vol.132, 75-89, 2009.

[25] E. Lipkovsky, S.S. Barinova, E. Nevo. Algal diversity dynamic and ecological mapping of streams in the Upper Jordan River, Northern Israel, Proceedings of the First International Conf. Bioindicators in monitoring of freshwater ecosystems, 23-27 October 2006, St.- Petersburg, 128-132, 2006.

[26] T. Zohary. Changes to the phytoplankton assemblage of Lake Kinneret after decades of a predictable, repetitive pattern, Freshwater Biology, Vol.49, 1355-1371, 2004.

[27] S.S. Barinova, O.V. Anissimova, E. Nevo, S.P. Wasser. Algae new for Israel from the Upper Nahal Oren River, Flora Mediterranea, Vol.13, 273-296, 2003

[28] M. Tavassi, S.S. Barinova, O.V. Anissimova, E. Nevo, S.P. Wasser. Algal indicators of the environment in the Nahal 
Yarqon Basin, Central Israel, International Journal on Algae, Vol.6, No.4, 355-382, 2004.

[29] S. Barinova, M. Tavassi, H. Glassman, E. Nevo. Algal indication of pollution in the Lower Jordan River, Israel, Applied Ecology and Environmental Research, Vol.8, No.1, 19-38, 2010.

[30] D.M. John, B.A. Whitton, A.J. Brook. The freshwater algal flora of the British Isles. An identification guide to freshwater and terrestrial algae, Cambridge University Press, Cambridge, 2002.

[31] A. Weber-van Bosse. Liste des Algues du Siboga. II. Rhodophyceae. Première partie. Protoflorideae, Nemalionales, Cryptonemiales, Siboga-Expeditie Monographie, Leiden, Vol.59, 187-310, 1921. 